\author{
Agnieszka Drzymała \\ University of Lodz, Faculty of Economics and Sociology \\ Institute of Economics \\ e-mail: adrzymala@uni.lodz.pl
}

\title{
Korporacje transnarodowe a standardy CSR w zakresie ochrony środowiska
}

\section{Transnational Corporations and CSR Standards in Environmental Protection}

The subject of this paper is the analysis of the factors that have the greatest importance regarding the implementation of the principles of social responsibility in transnational corporations. International standards for assessing corporate social responsibility define the framework and guidelines in the evaluation of the corporation in this regard. From the company's point of view, the involvement in social activities is used primarily for improving their own image. Companies try to reconcile the desire for profit with social considerations and environmental protection, however, this process is very complex. Corporations should carry out these policies and implement appropriate procedures. Additionally, consumers want to see the use of the CSR principles in practice, so corporations should measurably help the local community and/or support social organizations. In this context, the corporation may serve a wide audience, communities, and have a significant impact on the environment. The paper will attempt to answer the question regarding which factors affect the application of CSR in corporations.

Keywords: transnational corporations, CSR, environmental protection

JEL Classification: F23, M14, M16, Q56 


\section{Uwagi wstępne}

Celem artykułu jest próba opisu i analizy czynników, które mają największe znaczenie dla wprowadzenia zasad społecznej odpowiedzialności w korporacjach transnarodowych. Autorka podejmie próbę wyselekcjonowania prezentowanych w literaturze przedmiotu opinii, które przedstawiają różne punkty widzenia i klasyfikacje. W artykule zostanie również przeprowadzona analiza korzyści z wdrożenia zasad oraz analiza międzynarodowych standardów normalizacji i oceny CSR.

Międzynarodowe standardy oceny społecznej odpowiedzialności przedsiębiorstwa wyznaczają pewne ramy, wytyczne w dokonywaniu oceny korporacji pod tym względem. Natomiast z punktu widzenia korporacji zaangażowanie w działalność społeczną ma służyć przede wszystkim poprawie ich wizerunku. Próbują pogodzić chęć zysku ze względami społecznymi, jak i ochroną środowiska. Jednak ten proces jest bardzo złożony. Korporacje powinny prowadzić stosowną politykę oraz wdrażać odpowiednie procedury. W oczach konsumentów najważniejsze jednak jest stosowanie zasad CSR w praktyce. Zatem korporacja może służyć szerokiemu gronu odbiorców, społeczności i mieć istotny wpływ na ochronę środowiska. W tym kontekście można wysunąć następującą tezę: główne czynniki, które mają największe znaczenie dla wprowadzania zasad CSR w korporacjach można podzielić na dwie zasadnicze grupy: (1) służące poprawie wizerunku spółki oraz (2) służące wspomaganiu lokalnej społeczności lub/i wspomaganiu organizacji społecznych.

\section{Specyfika działalności korporacji transnarodowych}

Spośród wszystkich przedsiębiorstw wybrane zostały korporacje transnarodowe ponieważ to one właśnie, w przeciwieństwie do małych i średnich przedsiębiorstw, są w stanie i najpełniej realizują idee CSR. Takie dobrowolne działania podejmować mogą zwłaszcza duże przedsiębiorstwa, które stać na wprowadzanie zmian i ulepszeń. Skala ich działalności dodatkowo zwiększa możliwość wywierania wpływu na otoczenie, zarówno w kraju pochodzenia, jaki i w kraju lokaty bezpośrednich inwestycji zagranicznych. Wpływ ten może przyjąć zarówno wymiar korzystny (np. działania na rzecz społeczności lokalnej), jak i niekorzystny (np. przenoszenie tzw. „brudnych przemysłów” i zanieczyszczenie środowiska naturalnego kraju inwestycji bezpośredniej).

Korporacje transnarodowe postrzegane są obecnie jako główne podmioty stosunków międzynarodowych. Można odnieść wrażenie, i w niektórych przypadkach tak faktycznie jest, że upodobniają się do państw. Przejawia się to m.in. w: organizowaniu placówek o charakterze quasi-dyplomatycznym, stosowaniu flagi czy hymnu. Wymienione atrybuty kojarzą się właśnie z funkcjonowaniem państw. Wiele korporacji dysponuje zasobami i wpływami przewyższającymi państwa słabiej rozwinięte, co może owocować tym, że przejmują one zachowania dotychczas 
zastrzeżone tylko dla państw. W stosunkach międzynarodowych odnotowywane są przejawy specyficznej ,władzy” korporacji. Jednak mimo ich niezaprzeczalnie wysokiej pozycji, muszą brać pod uwagę innych uczestników życia gospodarczego, którzy nie są im podporządkowani. Często pozycja ta kojarzona jest z dominacją. Jednak tak naprawdę jest to zdolność do wywoływania pożądanych skutków bądź ukierunkowania zachowań, dzięki posiadanemu potencjałowi (np. zasobom kapitału, technologii, rozwiniętej sieci sprzedaży), który warunkuje zdolność manipulacji, wywierania silnego wpływu i poddawania innych podmiotów znaczącej presji ${ }^{1}$. Korporacje stanowią niezwykłą siłę i są katalizatorem procesów, które w bardzo istotny i skuteczny sposób modyfikują podstawowe parametry zarówno społeczne, jak i środowiska, implikując transformację pozycji i ról poszczególnych podmiotów funkcjonujących w jego ramach, a także zmianę charakteru ich wzajemnych rela$\mathrm{cji}^{2}$. Dlatego wdrażanie działań związanych z CSR w korporacjach jest tak istotne. Korporacje podejmując taką inicjatywę przyczyniają się do promowania pozytywnych wzorców postępowania zarówno w skali mikro-, jak i makroekonomicznej. Potwierdzają to różne rankingi. Związek pomiędzy rozmiarami przedsiębiorstwa i jego pozycją w publikowanych rankingach można powiązać ze stosowaniem zasad CSR. Im większe korporacje i im bardziej liczą się na globalnym rynku, tym chętniej stosują zasady CSR. Często zasady te są również ujmowane w strategii przedsiębiorstwa.

Według definicji UNCTAD korporacje transnarodowe to spółki składające się z przedsiębiorstwa macierzystego oraz filii, oddziałów znajdujących się za granicą. Mogą prowadzić działalność: produkcyjną, usługową lub handlową. Działalność ta musi być prowadzona na terenie co najmniej dwóch krajów ${ }^{3}$. Zatem cechą szczególną korporacji transnarodowych jest własność majątku i rozbudowana struktura organizacyjna, obejmująca własne jednostki i/lub jednostki powiązane kapitałowo ${ }^{4}$. Można wymienić następujące atrybuty korporacji ${ }^{5}$ :

(1) suwerenność - potencjał ekonomiczny korporacji, który może być większy niż potencjał, którym dysponują niektóre państwa;

(2) złożoność - znaczna liczba kluczowych i wzajemnie na siebie oddziaływujących elementów w systemie lub na określonej płaszczyźnie;

(3) rozproszenie - rozszerzenie zasięgu działania firmy na nowe lokalizacje w świecie;

(4) wiedza - kluczowy zasób informacji, wartości, reguł i doświadczeń;

(5) specjalizacja - podjęcie przez filię ściśle określonej działalności na potrzeby rynku ogólnoświatowego;

\footnotetext{
${ }^{1}$ M. Ciecierski, Korporacje transnarodowe jako uczestnik stosunków międzynarodowych [w:] Wspótczesna gospodarka światowa i jej podmioty w warunkach niestabilności, red. T. Sporek, tom 2 , Wydawnictwo Akademii Ekonomicznej im. Karola Adamieckiego w Katowicach, Katowice 2010, s. 217-227.

${ }^{2}$ Korporacje transnarodowe, http://stosunki-miedzynarodowe.pl/ (data dostępu: 26.01.2015).

${ }^{3}$ World Investment Report 2002. Transnational Corporations and Export Competitiveness, United Nations, New York and Geneva 2002, s. 291.

${ }^{4}$ A. Zorska, Korporacje transnarodowe. Przemiany, oddzialywania, wyzwania, Polskie Wydawnictwo Ekonomiczne, Warszawa 2007, s. 122-123.

${ }^{5}$ Ibidem, s. 126-132; A. Zorska, Ku globalizacji?: przemiany w korporacjach transnarodowych $i$ w gospodarce światowej, Wydawnictwo Naukowe PWN, Warszawa 2000, s. 50-57.
} 
(6) zdolność integrowania - umiejętność firmy do zmiany struktur organizacyjnych na bardziej zdecentralizowane, poprawa komunikacji i przystosowanie do wykorzystania nowoczesnych systemów informacyjnych;

(7) elastyczność - szybka i skuteczna adaptacja do zmian oraz dostosowanie do zmieniających się warunków panujących w otoczeniu zewnętrznym i wewnętrznym organizacji;

(8) sieciowość - stworzenie systemu obejmującego węzły i powiązania relacyjne;

(9) arbitraż - umiejętność wykorzystania istniejących na świecie dysproporcji o charakterze ekonomicznym, administracyjnym, geograficznym i kulturowym;

(10) globalna efektywność - wyraża aspekty działalności korporacji transnarodowych, których efekty i czynniki oddziałujące na siebie kształtują przychody firm.

Przedstawione poszczególne cechy mają wpływ na działanie korporacji, jednak najlepsze efekty uzyskuje się poprzez ich synergię. Zatem korporacja jawi się jako swego rodzaju organizm, interakcyjny system, który funkcjonuje w określony sposób $^{6}$. Z makroekonomicznego punktu widzenia korporacje są szczególnymi podmiotami gospodarki światowej, które ewaluują i konkurują na poziomie globalnym. Ich specyfika wynika z: faktu dysponowania wielkim potencjałem ekonomicznym, względnej niezależności finansowej oraz technologicznej i organizacyjnej, a niekiedy również politycznej. Jak wspomniano wcześniej, wykazując się wieloma cechami, atrybutami, właściwymi i zastrzeżonymi do tej pory dla państw, korporacje przełamały monopol państwa w wielu obszarach aktywności wewnętrznej i zagranicznej (przykład ochrony środowiska). Jednak zarówno korporacje, jak i państwa potrzebują siebie nawzajem. Korporacje funkcjonują w warunkach wykreowanych przez państwa z narzucanymi przepisami prawa, klimatem politycznym i szeregiem innych uwarunkowań. $Z$ drugiej jednak strony, aktywność korporacji oraz ich silne oddziaływanie na światowe procesy gospodarcze i społeczne, wpływa na reorganizację, zmianę i proces tworzenia nowych podmiotów - uczestników życia międzynarodowego ${ }^{7}$.

\section{Wdrażanie Systemu Zarządzania Środowiskiem w korporacjach transnarodowych}

W obecnym czasie można odnotować wzrost zainteresowania kwestiami ochrony środowiska w społeczeństwach. Dotyczy to również takich grup społecznych jak: pracownicy, kadra zarządzająca, ale również odbiorcy finalni dóbr i usług korporacji. Osobną, bardzo ważną grupą są akcjonariusze, którzy decydują o lokowaniu swojego kapitału. Korporacje idąc z duchem czasu mogą wykorzystać odpowiednie

\footnotetext{
${ }^{6}$ Ibidem.

${ }^{7}$ M. Ciecierski, Korporacje transnarodowe..., op. cit.
} 
instrumenty (prawne i finansowe) wspomagające zmniejszenie negatywnego oddziaływania na środowisko naturalne. Najczęściej jednak korporacje mają na uwadze poprawę wizerunku, która wpływa na ich pozycję w wymiarze globalnym. Zatem często decydują o wprowadzeniu do swojej strategii elementów ochrony środowiska. Z tego względu CSR powinna być traktowana tak jak inne strategie w przedsiębiorstwie. Najważniejszym, wstępnym zadaniem jest ustalenie odpowiedzi na pytanie: jakie specyficzne biznesowe cele ma wspierać strategia CSR? Jednak należy zaznaczyć, że wybrane problemy społeczne powiązane z celami nie powinny być oderwane od głównych umiejętności korporacji. Wtedy możliwe będzie tworzenie wartości dla firmy poprzez przyczynianie się do pomyślności społeczeństwa. Jednym z elementów niniejszego tematu jest tzw. zielony marketing, który wiąże się z procesem efektywnego wytwarzania społecznie pożądanych wyrobów i usług przy ograniczeniu zużywania zasobów przyrody i przestrzeganiu zasad ochrony środowiska naturalnego. Stosowanie wytycznych środowiskowych powoduje pojawienie się korzyści spowodowanych redukcją zużycia energii, zmniejszeniem zużycia materiałów czy projektowaniem podlegających recyklingowi opakowań ${ }^{8}$.

Zatem CSR jawi się jako potencjalne źródło uzyskania przewagi konkurencyjnej przez korporację. Zdecyduje się ona na wdrożenie zasad CSR, kiedy zaistnieje możliwość uzyskania pozytywnych efektów. Natomiast właściwy efekt może wystąpić tylko wtedy, kiedy każde społecznie odpowiedzialne działanie ze strony przedsiębiorstwa przyniesie pożądane korzyści społeczne, a każdy przejaw rozwoju społecznego spowoduje poprawę zdolności firmy do budowania przewagi konkurencyjnej. Zatem przedsiębiorstwo, chcąc sprawinie funkcjonować na globalnym rynku, musi uzyskać przewagę konkurencyjną. Jest ona efektem odpowiedniego wykorzystania potencjału konkurencyjnego, umożliwiającego efektywne generowanie atrakcyjnej oferty rynkowej i skutecznych instrumentów konkurowania. Obecnie CSR ma tu ogromne znacznie, korporacje osiągnęły już bowiem podobny poziom technologiczny i organizacyjny. $Z$ jednej strony, wprowadzenie CSR ma szansę stać się atrybutem, który będzie pozytywie wyróżniać korporację spośród innych, zapewniając jej właśnie przewagę konkurencyjną. Z drugiej strony, korzystnym efektem odpowiedniego wdrożenia CSR może być: lepszy rozwój społeczeństwa, poprawa stanu środowiska naturalnego oraz osiągnięcie innych celów zrównoważonego rozwoju? .

Znaczenie CSR w globalnej gospodarce cały czas rośnie. Może mieć to istotne znaczenie w przyszłości, ponieważ rozwiązanie ważkich problemów jak: zmiany klimatyczne, zanieczyszczenie wód i powietrza czy nadmierny konsumpcjonizm, wymaga nowych narzędzi oraz globalnego współdziałania. Wspólną płaszczyzną staje się zrównoważony rozwój. Efektywność i kompleksowość wdrażania zasad CSR w korporacjach ma kluczowe znaczenie w kontekście wkładu biznesu w rea-

\footnotetext{
${ }^{8} \mathrm{P}$. Brzustewicz, Społeczna odpowiedzialność przedsiębiorstwa jako narzędzie $w$ realizacji idei zrównoważonego rozwoju [w:] Polityka gospodarcza i finanse $w$ teorii i praktyce, red. A. Poszewiecki, G. Szczodrowki, Wyd. Instytut Wiedzy i Innowacji, Warszawa 2011, s. 254-267.

${ }^{9}$ Ibidem.
} 
lizację idei zrównoważonego rozwoju. Należy pamiętać, że korzystne efekty wdrażania CSR będą miały wymiar lokalny, jak również makroekonomiczny. Z tego powodu skuteczna implementacja CSR powinna uwzględniać m.in.: filozofię zarządzania całym przedsiębiorstwem, strategiczny wymiar CSR, zmianę orientacji marketingowej oraz przewagotwórczy wymiar CSR ${ }^{10}$.

Obecnie wiele korporacji deklaruje, że chce wspomagać proces ochrony środowiska naturalnego i jest gotowych na zmniejszanie swojego oddziaływania na środowisko. Pragną również wykazać, że podchodzą do ochrony środowiska poważnie, chcą np. racjonalnie wykorzystywać energię i wodę, surowce oraz bezpiecznie przechowywać i wykorzystywać zasoby. Takie korporacje decydują się na wdrożenie Systemu Zarządzania Środowiskiem.

Wdrożenie systemu i jego certyfikacja przedstawia korporację jako organizację, która ${ }^{11}$ :

(1) prowadzi działalność z uwzględnieniem swojej odpowiedzialności społecznej;

(2) realizuje w sposób kontrolowany procesy związane $\mathrm{z}$ istotnymi aspektami środowiskowymi;

(3) realizuje zadania zmierzające do osiągnięcia określonych celów środowiskowych oraz realizacji zadań i programów środowiskowych;

(4) zobowiązała się do: a) utrzymywania zgodności z prawem środowiskowym, b) zapobiegania zanieczyszczeniom, c) dążenia do ciągłej poprawy wyników na rzecz ochrony środowiska.

Korzyści, jakie korporacja może osiągnąć z wdrożenia Systemu Zarządzania Srodowiskiem to ${ }^{12}$ :

(1) zwiększenie konkurencyjności firmy - lepszy wizerunek firmy w oczach potencjalnych klientów i inwestorów;

(2) poprawa wizerunku organizacji jako odpowiedzialnej społecznie;

(3) ułatwienie dostępu do różnego rodzaju programów mających na celu dofinansowywanie działalności przedsiębiorstwa;

(4) uporządkowanie stanu formalnoprawnego - zgodność lub większe prawdopodobieństwo zgodności z wymaganiami prawnymi;

(5) łatwiejsze uzyskiwanie pozwoleń i zatwierdzeń, dzięki spełnieniu wymagań prawa,

(6) redukcja wytwarzania zanieczyszczeń i odpadów;

(7) redukcja kosztów usuwania odpadów i kosztów energii oraz opłat za korzystanie ze środowiska;

(8) lepsza współpraca i stosunki ze społeczeństwem, władzami oraz jednostkami kontrolującymi;

(9) nacisk położony na zapobieganie, a nie na działania korygujące powoduje obniżenie ryzyka środowiskowego, a przez to obniżenie mogących wystąpić kosztów kar i odszkodowań.

\footnotetext{
${ }^{10}$ Ibidem.

${ }^{11}$ Systemy Zarządzania Środowiskowego - informacje ogólne, http://www.iso.org.pl/ (data dostępu: 07.04.2014).

${ }^{12}$ Ibidem.
} 


\section{Standardy definiujące wymagania dotyczące Systemów Środowiskowych}

Najpopularniejsze obecnie standardy definiujące wymagania odnośnie do Systemów Srodowiskowych to ${ }^{13}$ :

(1) ISO 14001:2004 EMS - Ervironmental Management Systems, czyli System Zarządzania Środowiskowego (opracowany przez Międzynarodową Organizację Normalizacyjną);

(2) EMAS - Eco Management and Audit Scheme, czyli System Ekozarządzania i Audytu (dobrowolny system opracowany przez Komisję Europejską w 1993 r., rejestracja dotyczyła tylko przedsiębiorstw i innych organizacji z siedzibą na terenie UE; obecnie EMAS III - od 2010 r. ma zastosowanie na całym świecie) ${ }^{14}$

(3) FSC - Forest Stewardship Council, czyli System Certyfikacji Kontroli Pochodzenia Produktu oraz Gospodarki Leśnej;

(4) ISO 50001 - System Zarządzania Energią.

Dodatkowo elementy proekologiczne znajdują się również w innych standardach, takich jak ${ }^{15}$ :

(1) SQAS (Safety and Quality Assessment System), czyli System Badania i Oceny Bezpieczeństwa i Jakości opracowany przez Europejską Izbę Przemysłu Chemicznego w celu stworzenia warunków odpowiedzialnego i bezpiecznego obrotu produktami branży chemicznej. Jest to narzędzie służące zbadaniu i określeniu poziomu bezpieczeństwa i jakości działań operacyjnych podejmowanych $\mathrm{w}$ obrocie produktami chemicznymi zarówno obojętnymi, jak i niebezpiecznymi (podlegającymi ADR, RID, ADN) oraz materiałami szczególnego ryzyka (HCDG) przez podmioty funkcjonujące w łańcuchu logistycznym. Badanie SQAS kierowane jest do firm operujących w obszarze przewozów lądowych, drogowych i kolejowych, spedycyjnych, dystrybutorów produktów chemicznych, magazynów, terminali przeładunkowych, zakładów naprawczych cystern kolejowych i myjni cystern. Należy zaznaczyć, że badanie to wykonywane jest przez niezależnych, akredytowanych przez CEFIC audytorów ${ }^{16}$. Do firm, które już poddały się badaniu i ocenie zaliczyć można wielkich operatorów logistycznych i dystrybutorów. Zdecydowała tu świadomość konieczności prowadzenia swojej działalności w sposób bezpieczny, na profesjonalnym, wysokim poziomie jakościowym i w jak najmniejszy sposób

\footnotetext{
${ }^{13}$ Ibidem

${ }^{14}$ Europejski System Ekozarządzania i Audytu, www.ec.europa.eu/environment/emas (data dostępu: 26.01.2015).

${ }^{15}$ Ibidem

${ }^{16}$ SQAS Accredited Assessors.
} 
ingerującej w środowisko naturalne. Od 2001 roku firma Pharox na zlecenie Europejskiej Rady Przemysłu Chemicznego CEFIC uruchomiła elektroniczną bazę danych SQAS ${ }^{17}$.

(2) SQMS (McDonald's Supplier Quality Management System) - jest to standard dla firm, które dostarczają produkty żywnościowe do sieci fast food Mc Donald’s, z wyłączeniem dostawców mięsa. Wprowadzenie systemu pomaga w dostarczaniu bezpiecznych i najwyższej jakości produktów, które spełniają założone wymagania oraz przepisy i regulacje $\mathrm{e}^{18}$.

(3) Standardy poszczególnych globalnych koncernów charakteryzujące się zazwyczaj bardziej rygorystycznymi wymaganiami niż te przedstawione w popularnych standardach i wymaganiach prawa poszczególnych krajów, w których funkcjonują zakłady koncernów (np. Toyota, Toshiba).

Można wymienić następujące standardy ułatwiające normalizację działalności przedsiębiorstw w zakresie społecznej odpowiedzialności:

(1) Social Accountability 8000 (SA 8000) - jest to uniwersalna norma przeznaczona do stosowania w systemie niezależnej weryfikacji, określająca wymogi w zakresie odpowiedzialności społecznej, jakie dana firma powinna spełniać (przede wszystkim w obrębie relacji z pracownikami). SA8000 określa szereg warunków wstępnych (m.in. wolność zrzeszania się i prawo do negocjacji zbiorowych, niestosowanie dyskryminacji, nie stosowanie przymusu fizycznego lub psychicznego) oraz wymagania dotyczące systemu zarządzania odpowiedzialnością (m.in. sformułowanie polityki społecznej firmy, dokumentowanie zasad, sposobów realizacji i wyników, kontrolowanie dostawców w aspekcie polityki społecznej) $)^{19}$.

(2) Account Ability - Stakeholder Engagement Stanadard (AA 1000) - jest to narzędzie ułatwiające określenie celów strategicznych, mierzenie postępów w osiąganiu tych celów, przeprowadzanie audytu organizacji, opracowanie sposobu przedstawiania wyników i ich wykorzystywania w procesie dokonywania bilansu strategicznego. Dla każdego z tych zadań istotnym elementem jest zaangażowanie w budowanie relacji z poszczególnymi grupami interesariuszy oraz w konsekwencji - budowanie zaufania do organizacji i prezentowanego przez nią wizerunku ${ }^{20}$.

(3) Standard rekomendacji społecznej odpowiedzialności działania na rzecz zrównoważonego rozwoju i dobrobytu społeczeństwa (ISO 26000). Norma ISO 26000 Guidance on Social Responsibility ma zastosowanie do wszystkich organizacji - publicznych, prywatnych i non-profit, niezależnie od ich wielkości i lokalizacji, działających w krajach rozwiniętych

\footnotetext{
${ }^{17}$ Czym jest System SQAS ?, Safety \& Quality Assessment System, www.SQAS.pl (data dostępu: 02.05.2014).

${ }^{18}$ McDonald's Supplier Quality Management System, http://mcdonaldsmis.blogspot.com (data dostępu: 02.05.2014).

${ }^{19}$ B. Rok, Odpowiedzialny biznes $w$ nieodpowiedzialnym świecie, http://www.gap.uek.krakow.pl/ (data dostępu: 02.05.2014).

${ }^{20}$ AA1000 Stakeholder Engagement Standard (AA1000SES), www.accountability.org/ (data dostępu: 02.05.2014).
} 
i rozwijających się. Zawiera wytyczne dotyczące społecznej odpowiedzialności zdefiniowanej jako odpowiedzialność organizacji za wpływ podejmowanych przez nią decyzji i działań na społeczeństwo i środowisko poprzez przejrzyste i etyczne postępowanie, które ${ }^{21}$ : a) przyczynia się do zrównoważonego rozwoju, w tym zdrowia i dobrobytu społeczeństwa; b) uwzględnia oczekiwania interesariuszy (osób lub grup, które są zainteresowane decyzjami lub działaniami organizacji); c) jest zgodne z obowiązującym prawem i spójne z międzynarodowymi normami postępowania; d) jest zintegrowane $\mathrm{z}$ działaniami organizacji i praktykowane $\mathrm{w}$ jej działaniach podejmowanych w obrębie jej sfery oddziaływania.

Można wymienić następujące standardy ułatwiające raportowanie w zakresie CSR:

(1) Global Reporting Initiative (GRI) - instytucja działająca na rzecz rozwijania i propagowania tzw. wytycznych zrównoważonego rozwoju (Sustainability Reporting Guidelines). GRI opracowała wytyczne (ramowy system) sporządzania raportów społecznych uwzględniający wskaźniki i metody pomiaru. Mogą z nich korzystać wszystkie podmioty, które chcą składać kompleksowe sprawozdania ze swojej ekonomicznej, środowiskowej i społecznej działalności. GRI promuje wykorzystanie przez podmioty raportowania społecznego jako sposobu na zrównoważenie i przyczynianie się do zrównoważonego rozwoju. GRI jest pionierem i opracowała kompleksowy Sustainability Reporting Framework, który jest powszechnie stosowany na całym świecie. Raporty prezentują trwały trend i ład podmiotów, pokazują związek między strategią a zobowiązaniami płynącymi ze zrównoważonej gospodarki światowej ${ }^{22}$.

(2) DJSGI - Dow Jones Sustainability Group Indexes to rodzina 5. wskaźników: jeden globalny, trzy kontynentalne dla Ameryki Północnej, Europy i Azji oraz jeden wskaźnik krajowy dla Stanów Zjednoczonych. Przedsiębiorstwa, które w najwyższym stopniu spełniają kryteria objęte wskaźnikami Dow Jones Sustainability Group Indexes to: Bayerische Motoren Werke AG (BMW) - Niemcy, Australia \& New Zealand Banking Group Ltd - Australia, UPM-Kymmene OYJ - Finlandia, Akzo Nobel NV - Holaldia, GS Engineering \& Construction Corp - Korea Południowa ${ }^{23}$.

(3) Indeksy FTSE4Good - grupa indeksów giełdowych stworzona przez FTSE Company. FTSE4Good oferują szczegółowe wytyczne dla przedsiębiorstw, które chcą podjąć zobowiązania dotyczące społecznej odpowiedzialności lub rozszerzyć zakres już podjętych zobowiązań w tej sferze. Przedsiębiorstwa mające prawo ubiegać się o włączenie do indeksów FTSE4Good są oceniane w procesie uwzględniającym ponad 40 różnych kryteriów z trzech obszarów: a) systemu zarządzania środowiskowego, b) dialogu $\mathrm{z}$ interesariuszami, c) przestrzegania praw człowieka ${ }^{24}$.

\footnotetext{
${ }^{21}$ ISO 26000 Guidance on social responsibility, http://www.pkn.pl/iso-26000 (data dostępu: 02.05.2014).

${ }^{22}$ Global Reporting Initiative, www.globalreporting.org/ (data dostępu: 02.05.2014).

${ }^{23}$ O. Dębicka, A. Oniszczuk-Jastrząbek, Społeczna odpowiedzialność polskich przedsiębiorstw na tle wybranych krajów Unii Europejskiej, https://ekonom.ug.edu.pl/, (data dostępu: 02.05.2014).

${ }^{24}$ B. Rok, op. cit.
} 
Do standardów zarządzania środowiskowego, zarządzania jakością, bezpieczeństwem i higieną pracy w przedsiębiorstwie można zaliczyć:

(1) Programy czystszej produkcji - Cleaner Production Programmes ${ }^{25}$;

(2) Program europejskiego ekozarządzania i audytów środowiskowych EMAS Environmental Managemant and Audit Scheme ${ }^{26}$

(3) System zarządzania środowiskowego według standardów ISO serii $14001^{27}$

(4) System zarządzania jakością ISO $9001^{28}$;

(5) System zarządzania bezpieczeństwem i higieną pracy według norm OHSAS 18001/PN-N-1800129.

\section{Korzyści z wdrożenia zasad CSR w korporacjach transnarodowych}

Zastanawiając się nad czynnikami, które wpływają na stosowanie zasad CSR w korporacjach należy zaprezentować przede wszystkim korzyści wynikające z ich wdrażania. Wyniki przeprowadzonych wcześniej badań i opinie ekspertów wskazują na istnienie szeregu przykładów takich korzyści dla korporacji. I tak jako pierwszą można przedstawić opinię, że firma w sposób przemyślany i konsekwentny planuje swoje cele strategiczne w powiązaniu z koncepcją CSR i dlatego może osiągnąć wymierne korzyści, w tym ${ }^{30}$ :

(1) ukształtowanie długofalowych, opartych na zaufaniu, relacji z interesariuszami zewnętrznymi: społecznością lokalną, podmiotami współpracującymi, organizacjami pozarządowymi, inwestorami;

(2) zbudowanie przewagi konkurencyjnej oraz orientacja na długotrwały i stabilny wzrost;

(3) zwiększenie odporności na możliwość i skutki wystąpienia sytuacji kryzysowych;

(4) zbudowanie przejrzystej, opartej na współpracy oraz wysokich standardach etycznych, kultury organizacyjnej;

(5) ukształtowanie pozytywnego wizerunku, w tym wzmocnienie rozpoznawalności wśród interesariuszy wewnętrznych i zewnętrznych (m.in. społeczności lokalnej, opinii publicznej, analityków rynku);

\footnotetext{
${ }^{25}$ A. Matuszak-Flejszman, Wplyw uczestnictwa organizacji w programach lub systemach środowiskowych na doskonalenie systemu zarządzania środowiskowego zgodnego z wymaganiami normy ISO14001, „Zeszyty Naukowe Akademii Morskej w Szczecinie” 2009, 19 (91), s. 71-79.

${ }^{26}$ EMAS Environmental Managemant and Audit Scheme, www.emas.de (data dostępu: 02.05.2014).

${ }^{27}$ Systemy Zarządzania Środowiskowego..., op. cit.

${ }^{28}$ System Zarządzania Jakością zgodny z wymaganiami ISO 9001, http://www.iso.org.pl/iso-9001 (data dostępu: 02.05.2014).

${ }^{29}$ J. Ejdys, U. Kobylińska, A. Lulewicz-Sas, Zintegrowane systemy zarządzania jakościa, środowiskiem i bezpieczeństwem pracy, Oficyna Wydawnicza Politechniki Białostockiej, Białystok 2012, s. 136-194.

${ }^{30}$ A. Górny, Informacja w społecznej odpowiedzialności przedsiębiorstwa, s. 10, www.ur.edu.pl (data dostępu: 07.04.2014).
} 
(6) pozytywne postrzeganie przez potencjalnych kandydatów do pracy oraz wzrost poziomu satysfakcji pracowników, ich lojalności i motywacji;

(7) pozytywne postrzeganie władz spółki, które zainicjowały i podejmują działania w obszarze CSR, przez obecnych i potencjalnych inwestorów.

Jednak trzeba pamiętać, że w pierwszej fazie korporacja musi stworzyć odpowiednie warunki sprzyjające wdrażaniu zasad CSR. Często podejmowanie takiej inicjatywy kojarzone jest z budowaniem swojej konkurencyjnej pozycji na rynku. Obecnie jednak ważnym elementem jest postrzeganie odpowiedzialnego biznesu w szerszym, strategicznym kontekście, jako jednej z głównych funkcji przedsiębiorstwa. Dla każdej korporacji istotnym świadectwem sukcesu jest zysk, lecz w odniesieniu do CSR niezwykle ważna jest analiza wyników finansowych firmy w powiązaniu z efektami środowiskowymi i społecznymi podejmowanych decyzji.

Następna opinia opiera się na pięciu wyłącznie pozytywnych aspektach wdrożenia CSR w korporacji. Są to ${ }^{31}$ :

(1) poprawa wizerunku firmy,

(2) wzrost motywacji pracowników,

(3) wzrost przychodów,

(4) dodatkowe oszczędności,

(5) większa stabilność i przewidywalność sytuacji biznesowej.

Kolejna analiza wskazuje, że wprowadzenie CSR może przyczynić się do ${ }^{32}$ :

(1) poprawy wizerunku przedsiębiorstwa,

(2) stworzenia doskonałego fundamentu do redukcji kosztów, wdrażania innowacji,

(3) w znaczącym stopniu oddziaływania na całe otoczenie (np. w kwestii dbałości o środowisko przyrodnicze),

(4) poprawy pozycji konkurencyjnej podmiotu,

(5) satysfakcji ze świadomości prowadzenia działalności uwzględniającej oczekiwania otoczenia (wewnętrznego i zewnętrznego),

(6) wdrażania działań skierowanych do interesariuszy, makrootoczenia, środowiska.

Natomiast następna opinia wskazuje, że korzyści płynących z wdrożenia CSR jest wiele i zależą one od rodzaju podjętego działania w konkretnym przedsiębiorstwie. Najczęściej jednak widoczne korzyści odczuwane są w długim okresie, zazwyczaj przy wdrażaniu całego pakietu, swego rodzaju systemu. Korzyści dla przedsiębiorstwa można podzielić tu na dwie zasadnicze grupy ${ }^{33}$ :

(1) korzyści wewnętrzne - osiągnięte na skutek działań podjętych na rzecz interesariuszy wewnętrznych (takich jak: właściciele, inwestorzy, menedżerowie, pracownicy, związki zawodowe),

\footnotetext{
${ }^{31}$ PARP wspiera społeczną odpowiedzialność biznesu, Swiss Contribution, PARP, www.csr.parp.gov.pl, (data dostępu: 03.05.2014).

${ }^{32}$ M. Sznajder, Korzyści z wdrożenia koncepcji społecznej odpowiedzialności biznesu (z uwzględnieniem koncepcji interesariuszy), http://zneiz.pb.edu.pl, (data dostępu: 07.04.2014).

${ }^{33}$ Ibidem.
} 
(2) korzyści zewnętrzne - osiągnięte na skutek działań podjętych na rzecz interesariuszy zewnętrznych (takich jak: stowarzyszenia handlowe i branżowe, szkoły, uczelnie, rządy innych państw, władze centralne, władze lokalne, sądy, społeczność lokalna, organizacje pozarządowe, środowisko przyrodnicze, wierzyciele, dostawcy, klienci, konkurenci, media).

Do korzyści wewnętrznych zaliczyć można: budowanie poczucia, że istnienie przedsiębiorstwa jest korzystne dla jego otoczenia, budowanie przewagi konkurencyjnej, korzyści finansowe, minimalizacja ryzyka, mniejsza rotacja zatrudnienia, możliwość samorozwoju, penetracja nowych rynków, poczucie bezpieczeństwa zatrudnienia, poprawa komunikacji, poprawa kultury organizacyjnej, poprawa wizerunku przedsiębiorstwa, poprawa zarządzania, profesjonalizm działania, redukcja kosztów, wdrażanie innowacji, większa elastyczność, większa lojalność, większa motywacja, większa wiedza na temat otoczenia, większe bezpieczeństwo pracy, większe zaufanie, wyższa satysfakcja, wyższa wydajność, wyższy poziom inwestycji, wzrost wartości przedsiębiorstwa, wzrost zainteresowania inwestorów.

Korzyści zewnętrzne natomiast wiążą się z następującymi czynnikami: bezpieczeństwo i niezawodność produktu/usługi, budowanie poczucia, że istnienie przedsiębiorstwa jest z korzyścią dla jego otoczenia, czytelne i przejrzyste działania konkurencyjne, działania prewencyjne na rzecz ochrony środowiska naturalnego, kultura działań biznesowych, nakłady finansowe na rzecz ochrony środowiska, obniżenie ceny produktu/usługi, podniesienie jakości produktu/usługi, podniesienie wiarygodności finansowej firmy, poprawa komunikacji, profesjonalizm działania, przestrzeganie norm prawnych, racjonalna eksploatacja zasobów naturalnych, redukcja zanieczyszczeń, stymulacja rozwoju, tworzenie miejsc pracy, uczciwa konkurencja, większa lojalność, wspieranie przemian, współdziałanie, wyższy poziom inwestycji.

Innym podziałem korzyści dla korporacji z wdrożenia CSR jest podział ze względu na ich charakter. Można tu wyróżnić34: (1) korzyści finansowe, (2) korzyści pozafinansowe. Wytłumaczeniem takiego punktu widzenia jest pogląd, iż nie zawsze działalność przedsiębiorstwa przynosząca zyski jest pożądana przez otoczenie. Nie łatwo jest też wskazać konkretne profity ilościowe wynikające z zastosowania CSR w przedsiębiorstwie. Występuje bowiem trudność odniesienia działań społecznie odpowiedzialnych do efektów mierzalnych w kategoriach pieniężnych.

W kolejnej opinii przedstawione zostały korzyści wewnętrzne i zewnętrzne wdrażania CSR ${ }^{35}$. Do korzyści wewnętrznych należą: podniesienie poziomu kultury organizacyjnej, wzrost innowacyjności, poprawa atrakcyjności przedsiębiorstwa jako pracodawcy, pozyskanie i utrzymanie najlepszych pracowników, zwiększenie motywacji i zaangażowania pracowników, doskonalenie jakości zarządzania, zwiększenie produktywności, zwiększenie sprzedaży, lepsze przestrzeganie przepisów prawa, zmniejszenie kosztów, łatwiejszy dostęp do kapitału, dobrą informację i komunikację wewnątrz przedsiębiorstwa. Natomiast do korzyści zewnętrznych

\footnotetext{
${ }^{34}$ Ibidem

${ }^{35}$ E. Mazur-Wierzbicka, CSR $w$ dydaktyce, czyli jak uczyć studentów społecznej odpowiedzialności, Stowarzyszenie Kreatywni dla Szczecina, Szczecin 2012, s. 48.
} 
należą: wzrost efektywności prowadzonej działalności gospodarczej, wzrost zainteresowania inwestorów, wzrost konkurencyjności na rynku, pozyskiwanie nowych klientów i pogłębienie lojalności, budowanie pozytywnego wizerunku i reputacji przedsiębiorstwa, wiarygodność misji, łatwiejszy dostęp do mediów i upublicznienie działań, wpływ na kształtowanie polityki państwa, zrównoważony rozwój kraju lub regionu, promowanie zasad rozwiązywania konfliktów społecznych, ochrona środowiska.

Dodatkowo można przytoczyć opinię, wedle której korzyściami dla ekowydajnego przedsiębiorstwa są ${ }^{36}$ :

(1) obniżenie rachunków (za wywóz odpadów, zużycie energii itp.), a tym samym zwiększenie dochodowości firmy,

(2) wzrost konkurencyjności firmy,

(3) poprawa wizerunku przedsiębiorstwa.

Wszystkie przytoczone opinie wyodrębniające korzyści wdrażania CSR wskazują, że korporacje celowo włączają koncepcję CSR do celów strategicznych lub staje się ona jedną z głównych funkcji. Wdrażając jej zasady realizują cele własne m.in. związane z pozytywnym wizerunkiem oraz pozyskiwaniem klientów. W konsekwencji może to doprowadzić do poprawy pozycji konkurencyjnej podmiotu na rynku międzynarodowym. Większość opinii potwierdza, że implementacja zasad CSR to proces długotrwały i powinien być realizowany kompleksowo. Dodatkowo można podzielić korzyści wynikające $\mathrm{z}$ wdrażania zasad CSR na wewnętrzne i zewnętrzne oraz ze względu na ich charakter na: finansowe i pozafinansowe.

Korzyści z wdrażania zasad CSR można zaprezentować na modelowych przykładach niemieckich korporacji, takich jak: Siemens, Tchibo, Bosch, Deutsche Bank i Deutsche Telekom. Korporacje te skutecznie działają w różnych obszarach społecznej odpowiedzialności. Podejmują liczne inicjatywy sprzyjające ochronie środowiska naturalnego i wspomagające społeczeństwo. Można wymienić tu m.in. doskonalenie procesów zarządzania i kontroli jakości, edukację i kształcenie pracowników, organizowanie praktyk i pracy dla młodzieży, redukcję zużycia energii i zarządzanie recyklingiem ${ }^{37}$. Korporacje notują zatem takie korzyści jak posiadanie wykwalifikowanej kadry pracowniczej czy pozyskanie zaufania społecznego. Wszystkie wymienione korporacje są dobrze odbierane przez społeczeństwo, ich wizerunek jest niezachwiany i kojarzą się z produktami lub usługami wysokiej jakości. To powoduje, że ich konkurencyjność wzrasta.

Podsumowując można stwierdzić, że każda korporacja angażuje się w CSR na swój własny sposób, zależnie od swoich kompetencji, zasobów, interesariuszy, a także tradycji kulturowych, sytuacji społecznej i ekologicznej obszaru, w którym

\footnotetext{
${ }^{36}$ Materiały dla uczestników spotkania informacyjnego na temat społecznej odpowiedzialności biznesu organizowanego w ramach projektu „Zwiększenie konkurencyjności regionów poprzez społeczną odpowiedzialność biznesu (CSR)", SWISS CONTRIBUTION, PARP, www.csr.parp.gov.pl (data dostępu: 07.04.2014).

${ }^{37}$ S. Matuszewska, Siemens, Tchibo, Bosch -jak CSR robia najlepsi?, www.hrstandard.pl (data dostępu: 21.01.2016).
} 
funkcjonuje ${ }^{38}$. Pomimo dużych i systematycznie ponoszonych wydatków finansowych na wdrażanie CSR w korporacjach, za wprowadzeniem takich praktyk przemawia wiele argumentów, m.in.: wkład w rozwiązanie problemów społecznych, odciążenie środowiska naturalnego, poprawa wizerunku firmy, a w konsekwencji większe zaufanie i zadowolenie klientów oraz efektywność pracowników funkcjonujących w przyjaznym środowisku pracy. Jest to inaczej inwestycja w rozwój firmy, którą dokonują już niemal wszystkie znaczące korporacje w świecie. Wśród 100 największych niefinansowych korporacji transnarodowych w świecie (World Investment Report) nie ma takiej, która chociażby nie zaczęła wprowadzać koncepcji społecznej odpowiedzialności do swojej strategii. Należy podkreślić, że większość korporacji włącza do swoich podstawowych zadań strategicznych również aspekt ochrony środowiska, w tym innowacyjne rozwiązania dotyczące redukcji emisji $\mathrm{CO}_{2}$.

\section{Podsumowanie}

Funkcjonowanie korporacji transnarodowych na globalnym rynku jest skomplikowane, jawią się one często jako instytucje mające wiele zalet, jednak budzą również liczne kontrowersje i stanowią źródło dyskusji. Jedną z wielu zalet dostrzeganych przez interesariuszy jest wdrażanie zasad CSR. Obecnie większość korporacji określa odpowiedzialność społeczną jako ważny element strategii przedsiębiorstwa i podkreśla jej znacząca rolę przy ustalaniu celów firmy. Główne czynniki, które mają największe znaczenie dla wprowadzania zasad CSR w korporacjach można podzielić po pierwsze na te, które służą poprawie wizerunku spółki - wtedy korporacje próbują pogodzić chęć zysku ze względami społecznymi i ochroną środowiska. Odnoszą tzw. korzyść wewnętrzną. Drugą grupę stanowią te, które służą wspomaganiu lokalnej społeczności lub/i wspomaganiu organizacji społecznych - wtedy korporacje mogą służyć szerokiemu gronu odbiorców, społeczności i mieć istotny wpływ na ochronę środowiska. Wówczas odnoszą tzw. korzyść zewnętrzną.

Proces globalizacji, silna konkurencja i strategia utrzymywania już posiadanych rynków (oparta na budowaniu lojalności klientów) to najważniejsze czynniki, które wpływają na podejmowanie strategicznych decyzji przez korporacje. Choć ostateczną decyzję o wdrożeniu zasad CSR podejmują same korporacje, to niekiedy można zauważyć, że wywierany jest cichy nacisk na władze spółki zarówno przez odbiorców finalnych - klientów, jaki i akcjonariuszy, co wymusza podjęcie starań mających na celu spełnienie oczekiwań.

Przedstawione $\mathrm{w}$ artykule międzynarodowe standardy normalizacji i oceny CSR wyznaczają ramy i wytyczne w dokonywaniu oceny korporacji. Standardami definiującymi wymagania odnośnie do Systemów Środowiskowych są: ISO 14001, EMAS, FSC, ISO 50001. Dodatkowo elementy proekologiczne znajdują się rów-

\footnotetext{
${ }^{38}$ M. Ratajczyk, Implementacja strategii CSR $w$ odniesieniu do środowiska naturalnego jako ważny element strategii rozwojowych współczesnych przedsiębiorstw, http://www.wne.sggw.pl/ (data dostępu: 26.01.2015).
} 
nież w innych standardach, takich jak: SQAS, SQMS oraz standardach poszczególnych globalnych koncernów. Standardami ułatwiającymi normalizację działalności przedsiębiorstw w zakresie społecznej odpowiedzialności są: SA 8000, AA 1000 oraz ISO 26000. Natomiast standardy ułatwiające raportowanie w zakresie CSR to: GRI, DJSGI oraz Indeksy FTSE4Good.

\section{Bibliografia}

AA1000 Stakeholder Engagement Standard (AA1000SES), www.accountability.org/.

Brzustewicz P., Społeczna odpowiedzialność przedsiębiorstwa jako narzędzie $w$ realizacji idei zrównoważonego rozwoju [w:] Polityka gospodarcza i finanse w teorii i praktyce, red. A. Poszewiecki, G. Szczodrowki, Wyd. Instytut Wiedzy i Innowacji, Warszawa 2011.

Ciecierski M., Korporacje transnarodowe jako uczestnik stosunków międzynarodowych [w:] Współczesna gospodarka światowa i jej podmioty w warunkach niestabilności, red. T. Sporek, tom 2, Wydawnictwo Akademii Ekonomicznej im. Karola Adamieckiego w Katowicach, Katowice 2010.

Czym jest System SQAS?, Safety \& Quality Assessment System, www.SQAS.pl.

Dębicka O., A. Oniszczuk-Jastrząbek, Społeczna odpowiedzialność polskich przedsiębiorstw na tle wybranych krajów Unii Europejskiej, https://ekonom.ug.edu.pl.

Ejdys J., U. Kobylińska, A. Lulewicz-Sas, Zintegrowane systemy zarzadzania jakościa, środowiskiem i bezpieczeństwem pracy, Oficyna Wydawnicza Politechniki Białostockiej, Białystok 2012.

EMAS Environmental Managemant and Audit Scheme, www.emas.de.

Europejski System Ekozarządzania i Audytu, www.ec.europa.eu/environment/emas.

Global Reporting Initiative, www.globalreporting.org/.

Górny A., Informacja w spolecznej odpowiedzialności przedsiębiorstwa, www.ur.edu.pl.

ISO 26000 Guidance on social responsibility, http://www.pkn.pl/iso-26000.

Korporacje transnarodowe, http://stosunki-miedzynarodowe.pl.

Materiały dla uczestników spotkania informacyjnego na temat społecznej odpowiedzialności biznesu organizowanego $w$ ramach projektu „Zwiększenie konkurencyjności regionów poprzez społeczna odpowiedzialność biznesu (CSR)", SWISS CONTRIBUTION, PARP, www.csr.parp.gov.pl.

Matuszak-Flejszman A., Wpływ uczestnictwa organizacji w programach lub systemach środowiskowych na doskonalenie systemu zarzadzania środowiskowego zgodnego z wymaganiami normy ISO14001, „Zeszyty Naukowe Akademii Morskej w Szczecinie” 2009, 19(91).

Matuszewska S., Siemens, Tchibo, Bosch - jak CSR robia najlepsi?, www.hrstandard.pl.

Mazur-Wierzbicka E., CSR w dydaktyce, czyli jak uczyć studentów spotecznej odpowiedzialności, Stowarzyszenie Kreatywni dla Szczecina, Szczecin 2012.

McDonald's Supplier Quality Management System, http://mcdonaldsmis.blogspot.com. 
PARP wspiera społeczną odpowiedzialność biznesu, Swiss Contribution, PARP, www.csr. parp.gov.pl.

Ratajczyk M., Implementacja strategii CSR w odniesieniu do środowiska naturalnego jako ważny element strategii rozwojowych współczesnych przedsiębiorstw, http://www. wne.sggw.pl/.

Rok B., Odpowiedzialny biznes w nieodpowiedzialnym świecie, http://www.gap.uek.krakow.pl

System Zarządzania Jakością zgodny z wymaganiami ISO 9001, http://www.iso.org.pl/iso9001.

Systemy Zarządzania Środowiskowego - informacje ogólne, http://www.iso.org.pl/.

Sznajder M., Korzyści z wdrożenia koncepcji społecznej odpowiedzialności biznesu (z uwzględnieniem koncepcji interesariuszy), http://zneiz.pb.edu.pl.

World Investment Report 2002. Transnational Corporations and Export Competitiveness, United Nations, New York and Geneva 2002.

Zorska A., Korporacje transnarodowe. Przemiany, oddziaływania, wyzwania, Polskie Wydawnictwo Ekonomiczne, Warszawa 2007.

Zorska A., Ku globalizacji?: przemiany w korporacjach transnarodowych $i$ w gospodarce światowej, Wydawnictwo Naukowe PWN, Warszawa 2000. 